\title{
Diskresi dalam Penanggulangan Bencana di DIY dengan Paradigma Kontinjensi ${ }^{1}$
}

\author{
Ishviati Joenaini Koenti \\ Fakultas Hukum Universitas Janabadra Yogyakarta \\ Jln. Timoho II No.40, Muja Muju, Umbulharjo, Kota Yogyakarta \\ kunti.ishvi@gmail.com
}

\begin{abstract}
The main problem in this study is to examine the developments of the contingency plans that have not or have been made and whether it is activated or not. If it is activated, how is the evaluation of its implementation and if not activated, how is its monitoring and how is the supervision of its budget? The method used in this research is normative-juridical. The study concluded that not all contingency plans have been made in the types of disaster. Some contingency plans have been made. in Yogyakarta there are 4, 3 are in Sleman Regency, 3 in Kulonprogo and in Gunung Kidul. Overall, there are 8 contingency plans already implemented. For the places that have not been activated, the state is returned to the original condition. To follow-up and evaluation of post-contingency plan, the activation or inactivity should be uniform. It is necessary to put in the draft of Raperda on the changes in the draft of Regional Regulation About Disaster Management.
\end{abstract}

Keywords: Discretion, management, disaster

\begin{abstract}
Abstrak
Pokok permasalahan dalam penelitian ini mengkaji perkembangan rencana kontinjesi yang sudah maupun yang belum dibuat dan apakah sampai diaktifkan atau tidak. Jika diaktifkan bagaimana evaluasi pelaksanaannya, jika tidak diaktifkan, bagaimana pengawasannya serta bagaimana pengawasan anggarannya. Metode yang digunakan dalam penelitian ini yuridis normatif. Hasil penelitian menyimpulkan bahwa belum semua jenis bencana sudah dibuat rencana kontinjensi. Beberapa rencana kontinjensi sudah dibuat Kota Yogyakarta ada 4, Kabupaten Sleman 3, Kabupaten Kulon Progo 3 dan Kabupaten Gunung Kidul 3 , keseluruhan Rencana Konjinjensi yang sudah dilaksanakan ada 8. Untuk yang belum/tidak diaktifkan maka keadaan dikembalikan pada keadaan semula. Untuk tindak lanjut dan evaluasi pasca rencana kontinjesi aktivasi maupun tidak aktif perlu diseragamkan. Untuk itu perlu dimasukkan dalam draf raperda perubahan Peraturan Daerah Tentang Penanggulangan Bencana.
\end{abstract}

Kata-kata kunci: diskresi, manajemen, bencana.

${ }^{1}$ Hasil Penelitian Hibah Bersaing Kemenristek Dikti Th 2016 dengan judul: MODEL PENERAPAN DISKRESI PADA PEMERINTAHAN RESPONSIF: Pendekatan Kontigensi Pada Penanganan Bencana di DIY. 


\section{Pendahuluan}

Daerah Istimewa Yogyakarta (DIY) dan sekitarnya secara tektonik merupakan kawasan dengan tingkat aktivitas kegempaan yang cukup tinggi di Indonesia. Kondisi ini disebabkan wilayah tersebut berdekatan dengan zona tumbukan lempeng di Samudera Indonesia. Di samping akibat aktivitas tumbukan lempeng tektonik, daerah Yogyakarta juga sangat rawan gempa bumi akibat aktivitas sesar-sesar lokal di daratan. Kondisi tektonik semacam ini menjadikan Yogyakarta dan sekitarnya sebagai kawasan seismik aktif dan kompleks. Berdasarkan data sejarah kegempaan, DIY telah 12 kali mengalami bencana gempa bumi merusak, yakni pada 1840 dan 1859 yang juga terjadi tsunami, 1867 ( 5 tewas dan 327 rumah roboh), 1875, 1937 (2.200 rumah roboh), 1943 (250 orang tewas, 28 ribu rumah roboh), 1957, 1981, 1992, 2001, 2004, serta 2006 lalu. Jawa Tengah dan Yogyakarta, sesar-sesar lokal yang masih aktif dan jenis tanah yang gembur dengan kandungan air tanah cukup tinggi tampaknya telah mengamflikasi getaran gempa bumi².

Selain rawan gempa tektonik, Yogyakarta juga merupakan daerah yang berdekatan dengan gunung api yang aktif. Merapi termasuk gunung api yang sering meletus. Sampai Nopember 2013, erupsi yang tercatat sudah mencapai sekitar 100 kali kejadian. Secara rata-rata selang waktu erupsi Merapi terjadi antara 2-5 tahun (periode pendek), sedangkan selang waktu periode menengah setiap 5-7 tahun.

Bencana alam dan bencana kemanusiaan merupakan dua kondisi potensial yang mengancam keamanan dan keselamatan umat manusia (Human Security). Ancaman itu timbul bukan karena bencana alam semata, melainkan juga karena ulah dan perilaku manusia yang melampaui batas. Hubungan antara bencana alam dan tanggung jawab negara tercermin dalam Alinea IV Pembukaan UUD 1945. "Kemudian daripada itu untuk membentuk suatu pemerintahan negara Indonesia dan seluruh tumpah darah". Ketentuan tersebut menunjukkan adanya kewajiban negara untuk melindungi segenap masyarakat (State Legal Obligation), termasuk mereka yang menjadi korban bencana. Ketika dipersoalkan pentingnya Undang

\footnotetext{
${ }^{2}$ ugm.ac.id/id/berita, diakses tanggal, 4 Februari 2014.
} 
Undang Bencana Alam bagi upaya pencegahan korban bencana, maka pertanggungawaban dapat timbul ketika ada kelalaian dihadapi negara. ${ }^{3}$

\section{Rumusan Masalah}

Permasalahan penelitian ini adalah: pertama, bagaimana penerapan diskresi dalam konteks penanggulangan bencana? Kedua, bagaimana upaya yang harus dilakukan agar pemerintahan daerah mempunyai kesiapan untuk menghadapi bencana dan kemampuan untuk meminimalisir dampak bencana dengan paradigm kontinjensi?

\section{Tujuan Penelitian}

Adapun tujuan penelitian ini: pertama, melakukan pengkajian peraturan perundang-undangan kebencanaan. Kedua, mengkaji rencana kontinjensi yang sudah ada dan implementasinya pada saat terjadi bencana dan tidak terjadi bencana; Ketiga, mengkaji secara komprehensif yang dituangkan dalam draft akademik untuk menyiapkan peraturan daerah yang dapat digunakan oleh pejabat sebagai kerangka acuan.

\section{Metode Penelitian}

Metode yang digunakan adalah metode pendekatan hukum normatif dengan metode penelitian kualitatif. Dengan menggunakan teknik non-random sampling dan tidak menggunakan analisis statistik, mengumpulkan informasi verbal, detail, lengkap, bukan kuantitasnya. Hal ini sesuai dengan tujuan penelitian yang menganalisis berbagai peraturan kebijakan (dari strategi hingga operasional) yang dihasilkan dari penggunaan diskresi untuk penanggulangan bencana dan menganalisis serta memberikan rekomendasi penerapan diskresi yang ideal untuk penanggulangan bencana khususnya di Daerah Istimewa Yogyakarta.

Penelitian yang dilakukan adalah yuridis normatif, yaitu meneliti produk hukum yang dihasilkan dari penerapan diskresi dalam memecahkan masalah penanggulangan bencana. Jenis dan bahan yang digunakan dalam penelitian ini

${ }^{3}$ Jawahir Thontowi, "Urgensi Undang Undang Tentang Bencana Alam", Kedaulatan Rakyat, 2 Oktober 2006, hlm. 4 . 
adalah data primer dan data sekunder. Data primer diperoleh dari aparatur pemerintahan di DIY yang menggunakan diskresi, termasuk mantan-mantan pejabat (kepala daerah) yang pada waktu terjadi bencana meggunakan dikresi untuk menanggulanginya. Sedangkan data sekunder merupakan bahan hukum dalam penelitian yang di ambil dari studi kepustakaan yang terdiri dari bahan hukum primer, bahan hukum sekunder dan bahan non hukum. ${ }^{4}$ Dalam penelitian ini data sekunder diambil dari bahan hukum primer yaitu Peraturan perundangundangan, peraturan daerah, peraturan walikota dan peraturan pelaksanaan lainnya dan bahan hukum sekunder yaitu penjelasan berbagai peraturan perundang undangan dan dokumen pendukung lainnya.

Teknik pengumpulan bahan hukum melalui melakukan wawancara mendalam dengan narasumber studi kepustakaan dan, dokumentasi, triangulasi dan pengamatan, pengamatan melibat dan metode visual. Analisis dengan menggunakan data secara kualitatif yang dilakukan secara komprehensif dan lengkap, sehingga menghasilkan produk penelitian terapan yang lebih sempurna ${ }^{5}$ Dalam penelitian kualitatif, analisis data dilakukan sejak awal penelitian dan selama proses penelitian dilaksanakan. Data diperoleh, kemudian dikumpulkan untuk diolah secara sistematis. Dimulai dari penelusuran pustaka dan peraturan perundang undangan, wawancara, observasi, mengedit, mengklasifikasi, mereduksi, selanjutnya aktivitas penyajian data serta menyimpulkan data.

\section{Hasil Penelitian dan Pembahasan}

\section{Sejarah Bencana di Daerah Istimewa Yogyakarta ${ }^{6}$}

Sejarah bencana yang pernah terjadi di Daerah Istimewa Yogyakarta merupakan bencana alam dan non alam serta bencana sosial akibat ulah manusia. Terdapat 10 potensi bencana yang teridentifikasi berdasarkan sejarah kejadiannya. Kelompok potensi bencana tersebut dapat dilihat pada Tabel 1. Dari tabel tersebut maka dapat diuraikan lebih jelas beberapa kelompok kejadian bencana yang pernah terjadi di Daerah Istimewa Yogyakarta.

\footnotetext{
${ }^{4}$ Peter Mahmud Marzuki, Penelitian Hukum, Kencana, Jakarta, 2005, hlm. hlm.144.

5 Bambang Waluyo. Penelitian Hukum Dalam Praktik, Penerbit Sinar Grafika, Jakarta, 1991, hlm. 18

${ }^{6}$. BPDB DIY, Dokumen Perencanaan Daerah Istimewa Yogyàkàrtà, 2013-2017, DIPEROLEH DARI Kabid.Kesiapsiagaan dan Penanggulangan Bencana tgl. 12 Agustus 2016. hlm. 22-26
} 
Tabel 1.

Potensi Bencana Daerah Istimewa Yogyakarta7

\begin{tabular}{|c|c|}
\hline \multicolumn{2}{|c|}{$\begin{array}{l}\text { POTENSI BENCANA DAERAH ISTIMEWA YOGYAKARTA } \\
\text { BERDASARKAN CATATAN SEJARAH }\end{array}$} \\
\hline 1. Banjir & 7. Kekeringan \\
\hline 2. Epidemic dan wabah penyakit & 8. Letusan gunung api \\
\hline 3. Gelombang ekstrim \& Abrasi & 9. Angin Kencang \\
\hline 4. Gempa bumi & 10. Tanah longsor \\
\hline 5. Tsunami & 11. Kebakaran \\
\hline 6. Gagal teknologi & 12. Bencana Sosial \\
\hline
\end{tabular}

Untuk melihat catatan kejadian bencana yang pernah terjadi di Daerah Istimewa Yogyakarta dalam rentang waktu antara 1885-2011 dapat dilihat pada Data dan Informasi Bencana Indonesia seperti yang terlihat pada Tabel 2.

Tabel 2.

Catatan Data Bencana di Daerah Istimewa Yogyakarta 1885-20118

\begin{tabular}{|c|c|c|c|c|c|c|c|c|}
\hline Kejadian & 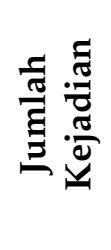 & 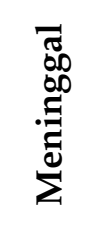 & $\begin{array}{l}\frac{\pi}{3} \\
\frac{\pi}{3} \\
\frac{\pi}{3} \\
\frac{\pi}{3}\end{array}$ & 趈 & 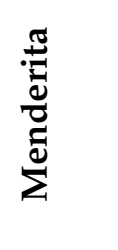 & 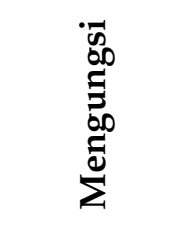 & 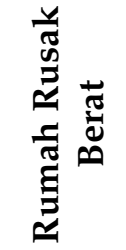 & 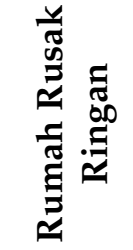 \\
\hline Banjir & 34 & 2 & 5 & - & 3.090 & 869 & 139 & - \\
\hline Epidemi \& Wabah & & & & & & & & \\
\hline $\begin{array}{l}\text { Penyakit } \\
\text { Gelombang Pasang / }\end{array}$ & 1 & 16 & - & - & - & - & - & 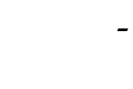 \\
\hline Abrasi & 1 & - & - & - & - & - & - & 29 \\
\hline Gempa Bumi & 10 & 4.923 & 22.406 & - & - & 1.403.617 & 95.903 & 107.048 \\
\hline Tsunami & 1 & 3 & 3 & - & - & - & - & - \\
\hline Kegagalan Teknologi & 2 & 75 & 119 & - & - & - & - & - \\
\hline Kekeringan & 34 & - & - & - & - & - & - & - \\
\hline Letusan Gunung Api & 7 & 4.249 & 186 & - & - & 10.759 & 2 & - \\
\hline Cuaca Ekstrim & 24 & 16 & 83 & - & - & 790 & 226 & 1.417 \\
\hline Tanah Longsor & 12 & 32 & 5 & - & - & 589 & 47 & 500 \\
\hline TOTAL & 127 & 9.316 & 22.807 & - & 3.090 & 1.416 .624 & 96.317 & 108.994 \\
\hline
\end{tabular}

${ }^{7}$ Sumber : Data \& Informasi Bencana Indonesia 1885- 2011.

${ }^{8}$ Sumber : Data \& Informasi Bencana Indonesia 1885-2011. 
Tabel 3.

Jumlah Kecamatan, Desa, dan Sekolah yang Berada di Wilayah Rawan Bencana DIY 9

\begin{tabular}{|llccc|}
\hline No & Kabupaten/Kota & $\begin{array}{c}\text { Jumlah } \\
\text { Kecamatan }\end{array}$ & $\begin{array}{c}\text { Jumlah Desa/ } \\
\text { Kel }\end{array}$ & $\begin{array}{c}\text { Jumlah } \\
\text { Sekolah }\end{array}$ \\
\hline 1 & Bantul & 17 & 69 & 911 \\
2 & Kulonprogo & 11 & 75 & 642 \\
3 & Gunungkidul & 18 & 124 & 1007 \\
4 & Sleman & 6 & 20 & 208 \\
5 & Kota Yogyakarta & 7 & 13 & 138 \\
\hline & JUMLAH : & $\mathbf{5 9}$ & 301 & $\mathbf{2 9 0 6}$ \\
\hline
\end{tabular}

Dari realitas yang ada bahwa DIY adalah daerah yang rawan bencana khususnya bencana alam, maka dibentuklan perangkat hukum sebagai landasan hukum dan landasan kebijakan, antara lain:

\section{Diskresi Sebagai Keputusan dan/atau Tindakan Penanggulangan Bencana di DIY Dengan Paradigma penanggulangan Pasca Bencana}

Diskresi pada dasarnya adalah sesuatu yang tidak dapat terelakkan baik bagi penerapan hukum itu sendiri maupun di dalam pelaksanan pemerintahan. Diskresi diperlukan sebagai pelengkap dari asas legalitas, yaitu asas hukum yang menyatakan bahwa setiap tindak atau perbuatan administrasi negara harus berdasarkan peraturan perundang-undangan yang berlaku. Menurut Bagir Manan setidaknya ada 2 (dua) penyebab keterbatasan dan kelemahan dari hukum tertulis yaitu: ${ }^{10}$

a. Hukum sebagai bagian dari masyarakat mencakup semua aspek dalam kehidupan yang sangat luas dan kompleks, sehingga tidak mungkin semua dijelmakan dalam bentuk peraturan perundang undangan tertulis.

b. Peraturan perundang undangan sebagaihukum tertulis pada umumnya bersifat statis yang tidak dapat dengan cepat mengikuti gerakan pertumbuhan, perkembangan dan perubahan masyarakat yang harus diembannya.

${ }^{9}$ Sumber : BPBD DIY, Disampaikan pada FGD dengan Tema "Diskresi Dalam Penanggulangan Bencana di DIY : Pendekatan Kontinjenji ” di Universitas Janabadra, 1 Oktober 2015.

${ }^{10}$ Bagir Manan dan Kuntoro Magnar, dirujuk Andi Nirwanto, "Arah Pemberantasan Korupsi ke DepanPasca Undang Undang Administrasi Pemerintahan”, Seminar Nasional HUT IKAHI, 26 Maret 2015, hlm.8 
Diskresi dalam hukum administrasi adalah suatu keniscayaan. Jika seorang pejabat administrasi pemerintahan harus menggunakan diskresi dalam pembuatan suatu keputusan administrasi pemerintah, pejabat yang bersangkutan wajib memperhatikan tujuan pemberian diskresi, batas-batas hukum yang berlaku serta kepentingan umum. Agar diskresi yang ada pada administrasi negara tersebut tidak disalah gunakan, maka diperlukan adanya tolok ukur pembatasan terhadap penggunaannya. Unsur-unsur yang harus dipenuhi oleh suatu diskresi adalah: ${ }^{11} \mathrm{a}$. ada karena adanya tugas-tugas pelayanan pulik (public service) yang diemban oleh administratur negara; b. dalam menjalankan tugas tersebut, para administratur negara diberikan keleluasaan dalam menentukan kebijakan-kebijakan; c. Kebijakan-kebijakan tersebut dapat dipertanggungjawabkan baik secara moral maupun hukum.

Diskresi pejabat admnistrasi memiliki kekuasaan bertindak dalam menghadapi persoalan- persoalan yang mendesak dikarenakan aturan belum ada, yang peraturannya tidak jelas atau memberikan pilihan, dan suatu keadaan yang mengakibatkan keadaan staknan, termasuk jika dihadapkan pada kondisi bencana. Pada dasarnya dalam keadaan semacam ini pejabat administrasi menentukan "apakah hukumnya" bagi permasalahan tersebut dan berkaitan dengan pertangunjawaban penyelesaian masalah. Yang-Yang dalam artikelnya "Fundamental Research on the Administrative Discretion Standard" mengemukakan bahwa standard diskresi administrasi harus memenuhi efisiensi bagi masyarakat. ${ }^{12}$ Menurut asal usul etimologinya ide diskresi adalah pertimbangan, khususnya pertimbangan yang baik, "according to its etymological, the idea of discration judgement particular good judgement" ${ }^{13}$

Menurut hukum responsif, diskresi diperluas tetapi tujuan yang hendak dicapai tetap pada tujuan. Untuk melakukan hal ini hukum responsif memperkuat cara-cara bagaimana keterbukaan dan integritas dapat saling menopang walaupun

\footnotetext{
${ }^{11}$ Sjachran Basah, Perlindungan Terhadap Sikap-Tindak. Administrasi Negara, Alumni, Bandung, 1992, hlm 3-5.

12 http:/ /dx.doi.org/10.4236/blr.2012.33017, Yang Yang, "Fundamental Research on the Administrative Discretion Standard” Beijing Law Review, 2012, 3, 128-132 diakses 10 Januari 2014.

${ }^{13}$ D J Galligan, Discretionary Power, Oxford Press University, New York, 1990, hlm. 8
} 
terdapat pertentangan diantara keduanya. Keadilan yang hakiki yang mengedepankan kepentingan dan kebutuhan/ kepentingan individu dan masyarakat, melalui proses pembuatan hukum partisipatif, fungsi hukum sebagai instrumen pelaksana kehendak rakyat. Tujuan menetapkan standar untuk mengkritisi praktik yang mapan, dan karenanya membuka jalan untuk melakukan perubahan. Pada saat bersamaan, jika benar-benar digunakan, tujuan dapat mengontrol diskresi administratif dan dengan demikian dapat mengurangi resiko terjadinya pelepasan institusional. ${ }^{14}$

Menurut Paripurno dalam Liesnoor ${ }^{15}$, bencana merupakan fenomena yang terjadi karena komponen-komponen pemicu, ancaman, dan kerentanan bekerja bersama secara sistematis, sehingga menyebabkan terjadinya risiko pada komunitas. Definisi bencana menurut UU No. 24 Tahun 2007 adalah peristiwa atau rangkaian peristiwa yang mengancam dan mengganggu kehidupan dan penghidupan masyarakat yang disebabkan, baik oleh faktor alam dan/atau faktor non alam maupun factor manusia sehingga mengakibatkan timbulnya korban jiwa manusia, kerusakan lingkungan, kerugian harta benda dan dampak psikologis.

Setelah bencana terjadi, manajemen bencana harus dipahami sebagai suatu siklus pengelolaan yang utuh, menerus, dan sinergis yang terdiri dari: (1) pengelolaan darurat, (2) rehabilitasi, (3) rekontruksi, (4) pembangunan, (5) pencegahan, (6) mitigasi / pengurangan dampak, serta (7) kesiap-siagaan, yang termasuk di dalamnya pengembangan sistem peringatan dini. Sementara ini, bencana alam cenderung dikelola dengan pendekatan "akibat". Terutama melakukan tindakan-tindakan gawat darurat, misalnya pencarian korban pengungsian. Upaya ini cenderung tidak akan menyelesaikan masalah. Oleh karenanya, perlu dipertimbangkan untuk segera melakukan pengelolaan bencana dengan pendekatan "sebab", dengan melakukan pengurangan kerentanan. Menurut International Strategy for Disaster Reduction (ISDR), suatu gangguan serius terhadap keberfungsian suatu masyarakat, sehingga menyebabkan kerugian yang meluas pada kehidupan manusia dari segi materi, hlm. 100

${ }^{14}$ Phillipe Nonet dan Philip Selznick, Hukum Responsif, (terj: Raisul Muttaqien), Nusamedia, Bandung, 2007,

${ }^{15}$ Liesnoor Dewi, Erosi dan Mitigasi Bencana, (Buku Ajar) Jurusan Geografi, Semarang, UNNES, CV. Sanggar Krida Aditama, 2010, hlm.12. 
ekonomi atau lingkungan dan melampaui kemampuan masyarakat yang bersangkutan untuk mengatasi dengan menggunakan sumber daya mereka sendiri.

Ada dua model pendekatan dalam manajemen bencana khususnya terhadap bantuan darurat yaitu "konvensional" dan "pemberdayaan". Perbedaan kedua pendekatan tersebut terutama terletak kepada cara "melihat" : (1) kondisi korban, (2) taksiran kebutuhan, (3) kecepatan dan ketepatan, (4) fokus yang dibantukan; (5) target akhir. Risiko Bencana adalah potensi kerugian yang timbul akibat bencana pada suatu wilayah dan kurun waktu tertentu yang dapat berupa kematian, luka, sakit, jiwa terancam, hilangnya rasa aman, mengungsi, kerusakan atau kehilangan harta, dan gangguan kegiatan masyarakat. Ancaman adalah Suatu kejadian atau peristiwa yang bisa menimbulkan bencana. UU No 24 Tahun 2007 menyebutkan ada 3 ancaman; ancaman yang bersifat alamiah, non alamiah dan kemanusiaan. Ancaman yang ada baru berpotensi memunculkan kematian, memunculkan korban, penderitaan dan lain-lain sehingga ancaman bisa terjadi dan bisa tidak. Ancaman bisa saja muncul bahkan meskipun penanganannya sudah bagus. Akan tetapi apabila perencanaan sudah baik dan persiapan sudah mencukupi, maka ancaman munculnya korban dan terjadinya kematian bisa tidak terjadi. Gempa, banjir dan tsunami adalah ancaman.

Dengan paradigma yang konvensional, bencana yang terjadi pada umumnya ditanggulangi pasca terjadinya bencana. Dalam penelitian ini beberapa kejadian yang ditanggulangi pasca bencana antara lain adalah sebagai berikut:

\section{Penggunaan Diskresi dalam Penyelesaian Permasalahan Recovery Bangunan Terdampak Gempa Bumi di Bantul}

Bupati Bantul mengeluarkan Peraturan Bupati Nomor 11 B Tahun 2006 tentang Pembebasan Pungutan Ijin Mendirikan Bangunan dan Peraturan Bupati Nomor 07 Tahun 2007 tentang Pelaksanaan Rehabilitasi dan Rekonstruksi Rumah dan Pengurusan Ijin Mendirikan Bangunan Pasca Gempa Bumi di Kabupaten Bantul dan Peraturan Bupati Bantul Nomor 07 Tahun 2007 tentang Pelaksanaan Rehabilitasi dan Rekonstruksi Rumah dan Pengurusan Ijin Mendirikan Bangunan Pasca Gempa Bumi di Kabupaten Bantul. Isi kedua Peraturan Bupati ini 
"menyimpangi" Peraturan Daerah Kabupaten Bantul Nomor 7 Tahun 2002 tentang Ijin Mendirikan Bangunan. Dalam keadaan normal pembangunan bangunan wajib memiliki IMB. Dalam keadaan darurat maka pejabat berkewajiban untuk menyelesaikan permasalahan yang ada dengan menggunakan diskresi. Dasar pertimbangan dari kedua peraturan bupati tersebut dimungkinkan dengan adanya wewenang diskresi dengan menerapkan asas-asas umum pemerintahan yang baik, terutama asas kepastian hukum, asas bertindak cermat dan kehati-hatian, memiliki alasan dan dasar fakta, menanggapi pengharapan yang wajar dan asas kemanfaatan.

\section{Penanganan Bencana Erupsi Merapi di Sleman (2010)}

Setelah erupsi Gunung Merapi pada 21 Oktober 2010 dan 6 Nopember tahun 2010 yang lalu, Kepuharjo menjadi lokasi dengan tingkat kerusakan terparah. Seluruh dokumen desa Kepuharjo yang tersimpan di Kantor Kelurahan hangus. Lebih dari 90\% infrastruktur hancur, jalan penghubung antar desa hancur baik terkena awan panas, abu maupun lahar dingin. Dari 8 pedukuhan di desa Kepuharjo tersisa 2 pedukuhan saja yang masih tersisa infrastrukturnya, yaitu dukuh Batur dan Pagerjuran. Saat itu 75\% wilayah Kepuharjo yang meliputi 6 pedukuhan tertutup muntahan lahar panas saat erupsi dan dinyatakan sebagai Kawasan Rawan Bencana (KRB) sehingga tidak dapat dipakai sebagai kawasan hunian lagi. Lahan pertanian, peternakan dan kehutanan pun luluh lantak. Demikian pula sumber aktifitas perekonomian, baik modal, sarana prasarana maupun tempat-tempat usaha tidak dapat digunakan lagi. Hal ini tentu saja menyebabkan timbulnya keadaan baru yang sangat jauh berbeda sebelum erupsi Merapi. ${ }^{16}$

Akibat bencana yang menimbulkan dampak yang besar kepada masyarakat dan penanggulangan bencana alam memerlukan kecepatan dan ketepatan bertindak, perlu ditetapkan status keadaaan darurat bencana. Bupati Sleman berdasarkan diskresi yang ada pada jabatan bupati mengeluarkan Keputusan Bupati Sleman Nomor: 322/Kep.KDH/A.2010 tentang Status Keadaan Darurat Bencana. Keputusan tersebut berisi pertama; status keadaan darurat bencana, yaitu

\footnotetext{
${ }^{16}$ Hasil Wawancara dengan Kepala Desa Kepuharjo, tanggal 12 Fabruari 2013 dan dilengkapi dengan wawancara pada tanggal 23-24 Maret 2015.
} 
siaga gunung api Merapi dan darurat bencana hidrometereologis. Kedua, instansi terkait bersama sama masyarakat untuk dapat mengambil langkah langkah penanggulangan bencana secara koordinatif. Diskresi digunakan untuk mengatasi permasalahan recovery pasca erupsi. Keputusan Bupati yang dibuat dengan mendasarkan pada wewenang diskresi digunakan sebagai dasar hukum tindakan yang berupa pembangunan hunian tetap (huntap).

Disimpulkan tingkat kepuasan pelayanan/ penanganan pasca erupsi merapi pada warga yang menghuni huntap yang ada di Kepuharjo, sejumlah 400 responden penghuni huntap menunjukkan: tidak memuaskan $1 \%$, kurang memuaskan 2,3, cukup memuaskan, Memuaskan 54,5\%, sangat memuaskan 18,5\%, $14,7 \%$ up stain. Untuk fasilitas hunian, diperoleh data $0 \%$ tidak puas, 3,7\%, cukup memuaskan 32,6, memuaskan 63\% dan sangat menuaskan 0,9\%. Peran Pemerintah diperoleh data tidak memuaskan 3,2\%, cukup memuaskan 15,2\%, Memuaskan $24 \%$, Sangat Memuaskan 6. 53\%. Namun dari pertanyaan yang sifatnya terbuka diperoleh informasi bahwa sebagian besar penghuni huntap mengeluhkan kesulitan transportasi bagi petani untuk menuju tempat berladang (tanah-tanah tempat berladang yang termasuk dalam ketentuan wilayah rawan bencana, yang hanyak boleh digunakan untuk berladang saja, tidak diperbolehkan untuk tempat tinggal). Sebagian penghuni juga mengeluhkan ketiadaan pekerjaan yang layak dan mengharapkan penghidupan seperti sebelum terjadi erupsi Merapi.

\section{Penggunaan Diskresi dalam Penyelesaian Permasalahan Banjir Lahar Dingin Merapi di Kawasan Bantaran Kali Code (2011)}

Kali Code yang berhulu di puncak Merapi mendapat limpahan material vulkanik yang terbawa banjir lahar dingin. Banjir lahar dingin paling tidak telah terjadi dua kali sampai akhir 2010 dan menggenangi beberapa wilayah yang mengakibatkan tertutupnya beberapa ruas jalan di Sleman dan Kota Yogyakarta. Beberapa titik talut yang mengalami kerusakan parah akibat aliran lahar dingin itu antara lain, di Tegalpanggung dekat jembatan Sayidan, Jembatan Tungkak dan Jembatan Wirosaban. Material yang terbawa banjir lahar dingin seperti kayu dan pohon tersangkut di jembatan tersebut hingga aliran banjir lahar dingin melompat dan 
membahayakan masyarakat sekitar, dari 66 RW yang berada di bantaran Kali Code, sebanyak 47 RW diantaranya terendam aliran banjir lahar dingin luapan dari Kali Code Luapannya bervariasi ada yang hanya 30 centimeter tetapi ada yang lebih dari satu meter tergantung ketinggian wilayah dari bibir Kali Code sendiri. ${ }^{17}$ Pengerukan dengan menggunakan alat berat (backhoe) mengalami beberapa kendala yaitu: 1. Keterbatasan dana: pengoperasian backhoe membutuhkan biaya yang besar mengingat pengoperasannya dihitung perjam; 2. Medan sungai yang tidak rata, dan menyempit mengakibatkan backhoe tidak dapat masuk ke tengan aliran sungai; 3. Secara teknis kerja backhoe lambat; 4. Kendala SDM (sopir backhoe tidak selalu sanggup melaksanakan tugas).

Walikota Yogyakarta dengan menggunakan diskresi dengan dikeluarkannya Keputusan Walikota Yogyakarta Nomor : 762/KEP/2010 Tentang Mekanisme Pengerukan dan Pengambilan Material Lahar Dingin di Sungai Code sebagai Bagian dari Program Tanggap Darurat Antisipasi Bencana Lahar Dingin Gunung Merapi , Pertimbangan dikeluarkan Keputusan Walikota Yogyakarta Nomor : 762 /KEP /2010 adalah dalam rangka menindak lanjuti penetapan status bencana banjir lahar dingin dan permohonan masyarakat untuk mengurangi dampak pendangkalan kali Code sehingga perlu pengerukan. Dalam pelaksanaan pengerukan tersebut perlu ada mekanisme pengerukan dan pengambilan materi lahar dingin di kali Code.

Keputusan Walikota Yogyakarta Nomor : 762 /KEP /2010 dapat menyelesaikan masalah masalah yang timbul dalam pengerukan dan pengmbilan pasir lahar dingin di sungai Code. Permasalahan yang dapat diselesaikan antara lain: 1. Area pengerukan dapat diperluas; 2. Dengan diperluasnya area dan akses pengerukan material di hampir semua titik rawan banjir maka bentrok antar masyarakat dikawasan yang mendapat bantuan pengerukan dan dapat dihindari; 3. Terbangunnya lingkungan sosial dengan pemberdayaan masyarakat melalui LPMK. Filosofi kebijakan pembangunan Pemkot Jogja adalah "dari, oleh dan untuk

17.Hasil wawancara peneliti dengan Kepala Dinas Kimpraswil tanggal 26 Agustus 2012. 
masyarakat". Artinya implementasi kebijakan pembangunan mengedepankan dan berbasis partisipasi/dukungan masyarakat.

\section{Penerapan Diskresi untuk Mengatasi Dampak Abu Gunung Kelud}

Pada bulan Februari 2014 kejadian bencana yang menonjol terjadi di DIY adalah hujan abu sebagai dampak letusan Gunung Kelud. Gunung Kelud yang terletak di Kabupaten Kediri, Jawa Timur yang meletus pertama kali pada pukul 22.50 WIB tanggal 13 Februari 2014. Gubernur DIY Sri Sultan Hamengku Buwono (HB) X langsung mengeluarkan surat keputusan status tanggap darurat akibat gangguan abu vulkanik erupsi Gunung Kelud. Keputusan ini diambil karena wilayah DIY terkena dampak erupsi Gunung Kelud berupa hujan abu vulkanik. Seluruh wilayah Provinsi DIY tertutup abu vulkanik. Adapun isi Surat Keputusan bernomor 27/KEP/2014 adalah Provinsi DIY dinyatakan dalam Status Tanggap Darurat Akibat Gangguan Abu Vulkanik Dampak Letusan Gunung Kelud selama tujuh hari, dimulai 14 Februari sampai 20 Februari. Guna menindaklanjuti Surat Keputusan Gubernur DIY Nomor 27/KEP/2014, yang menetapkan Yogyakarta darurat abu vulkanik letusan Gunung Kelud.

\section{Kebijakan Penanggulangan Bencana Pemerintah Daerah Yogyakarta}

Akhir 2010, DIY telah memiliki Perda Nomor 10 Tahun 2010 tentang Penanggulangan Bencana. Namun Perda tersebut masih berparadigma penanggulangan Bencana dalam arti pasca terjadi bencana, oleh sebab itu perlu dibuat rencana peraturan daerah yang lebih berbasis pada pengurangan risiko bencana. Paradigma pembangunan tersebut telah mengilhami gerakan bersama antara Pemerintah, Pemerintah Daerah, masyarakat, dan lembaga usaha di daerah untuk secara bersama-sama mengerahkan potensi yang dimiliki untuk meningkatkan ketangguhan daerah terhadap ancaman bencana agar sistem penanggulangan bencana daerah lebih responsif dan konstruktif. Pengelolaan penanggulangan bencana dilaksanakan salah satunya melalui pemberdayaan masyarakat, termasuk juga memperhatikan kearifan lokal yang ada di masyarakat. Perda ini digunakan sebagai landasan Peraturan Gubernur Daerah Istimewa Yogyakarta Nomor: 81 Tahun 2013 tentang Rencana Penanggulangan Bencana 
Daerah Istimewa Yogyakarta 2013 - 2017. Isi peraturan ini antara lain: membentuk dan memberdayakan forum/jaringan daerah, khususnya untuk pengurangan risiko bencana. Sesuai dengan visi, misi, dan tujuan penyelenggaraan penanggulangan bencana, maka disusunlah kebijakan penanggulangan DIY yang difokuskan untuk menurunkan kerentanan dan meningkatkan kapasitas, mengingat problem utama atau root of the problem dalam penanggulangan bencana adalah masih relatif tingginya kerentanan dan masih relatif rendahnya kapasitas, maka penyelenggaraan penanggulangan PB diarahkan pada penurunan kerentanan (V) dan peningkatan kapasitas (C). Potensi bencana di DIY menurut dokumen Rencana Penanggulangan Bencana DIY-2013-2017: Gempa bumi, tanah longsor, tsunami, gelombang ekstrim, banjit, letusan gunung api, kekeringan, cuaca ekstrim, kebakaran hutan, epidemic dan wabah penyakit, kegagalan teknologi dan konflik sosial ${ }^{18}$. Penekanan rencana kontinjensi pada kesiapsiagaan bencana yaitu: suatu proses yang mengarah pada kesiapan dan kemampuan untuk memperkirakan kejadian bencana sehingga dapat: mencegah bencana, mengurangi dampak mereka, menanggapi secara efektif memulihkan diri dari dampaknya. ${ }^{19}$

Masing-masing elemen pokok-pokok strategi dalam manajemen penanggulangan bencana dilaksanakan dengan kebijakan sebagai berikut: 1 . Penguatan kelembagaan Badan Penanggulangan Bencana Daerah selaku koordinator, komando dan pelaksana penanggulangan bencana di daerah; 2. Penguatan kesiapsiagaan pada semua tingkatan masyarakat dan dunia usaha; 3. Melakukan identifikasi dan Kajian Risiko Bencana; 4. Membangun Sistim Peringatan Dini yang handal; 5. Melaksanakan pemantauan dan evaluasi pelaksanaan program pengurangan risiko bencana; 6. Mengarusutamakan Pengurangan Risiko Bencana dalam rencana pembangunan daerah; 7. Perencanaan penanggulangan bencana yang terpadu dan komprehensif; 8. APBD yang berperspektif pengurangan risiko bencana; 9 . Mendayagunakan rencana tata ruang wilayah sebagai untuk mengurangi risiko bencana; 10. Menyusun regulasi

${ }^{18}$ Materi Kepala bidang pencegahan dan kesiapsiagaan BPBD Prov. DIY pada FGD, "Rencana Kontinjensi Pada Penanganan Bencana dengan Menitik Beratkan pada Pencegahan dan Kesiap Siagaan" di Universitas Janabadra, tanggal. 4 Oktober 2016.

19 Simpulan dari hasil FGD, tanggal 4 Oktober 2016. 
penanggulangan bencana sesuai dengan kebutuhan daerah; 11. Menyusun mekanisme, standar dan kerangka kerja penanggulangan bencana; 12. Peningkatan kualitas sumberdaya aparatur yg memiliki kompetensi dalam penanggulangan becana; 13. Menyediakan sarana dan prasarana penanggulangan bencana yang handal; 14. Mengembangkan sistem informasi manajemen sumber daya penanggulangan bencana; 15. Melaksanakan Penelitian, pendidikan dan pelatihan penanggulangan bencana; 16. Mengkampanyekan budaya sadar bencana; 17. Membentuk dan mengembangan desa/kelurahan tangguh bencana; 18 . Mengintegrasikan pengurangan risiko bencana ke dalam program pendidikan; 19. Membentuk forum multipihak dalam penanggulangan bencana; 20. Membangun jejaring dengan lembaga penanggulangan bencana; 21. Mengembangkan Sistem Komando Tanggap Darurat; 22. Melakukan review dan simulasi rencana konjitensi dan darurat bencana secara berkala; 23. Pemulihan menjadi sebuah kesempatan membangun dengan lebih baik.

\section{Rencana Kontinjensi sebagai Pendukung Penerapan SOP Penanggulangan Bencana Prioritas di DIY Konsep-Konsep Utama Pedoman Perencanaan Kontinjensi}

Berbagai definisi Rencana Kontinjensi diberikan oleh UNISDR (Strategi Internasional untuk Pengurangan Bencana PBB), IASC, Federasi Internasional, dan BNPB. Definisi UNISDR, Rencana Kontinjensi adalah : Proses manajemen yang mengalisis kejadian potensial tertentu atau situasi yang timbul yang mungkin mengancam masyarakat dan lingkungan dan menyusun pengaturan di muka untuk memungkinkan tanggapan yang tepat waktu, efisien, dan patut terhadap kejadian atau situasi seperti itu. Defini IASC: Perencanaan kontinjensi adalah proses membentuk tujuan, pendekatan dan prosedur program untuk menanggapi situasi atau kejadian yang cenderung terjadi, yang meliputi upaya mengidentifikasi kejadian serta mengembangkan skenario yang mungkin dan rencana yang patut untuk menyiapkan diri terhadap dan menanggapi kejadian itu secara efektif. Federasi Internasional: Berdasarkan kejadian tertentu atau risiko yang diketahui pada tingkat lokal, nasional, regional, dan global (misalnya gempa 
bumi, banjir) atau wabah penyakit untuk membentuk prosedur operasional bagi tanggapan, berdasarkan kebutuhan dan kapasitas sumber daya yang diperkirakan guna memungkinkan tanggapan yang tepat waktu, efektif, dan patut. BNPB: Proses perencanaan ke depan, dalam keadaan tidak menentu, dimana skenario dan tujuan disepakati, tindakan teknis dan manajerial ditetapkan, serta sistem tanggapan dan pengerahan potensi disetujui bersama untuk mencegah, atau menanggulangi secara lebih baik keadaan atau situasi darurat yang dihadapi ${ }^{20}$

BPBD DIY mendefinisikan Rencana Kontinjensi adalah suatu proses identifikasi dan penyusunan rencana yang didasarkan pada keadaan kontinjensi atau yang belum tentu tersebut. Suatu rencana kontinjensi mungkin tidak selalu pernah diaktifkan, jika keadaan yang diperkirakan tidak terjadi. ${ }^{21}$ Akan tetapi, istilah perencanaan kontinjensi digunakan untuk berbagai kegiatan, dalam konteks yang beragam, untuk menjawab beberapa pertanyaan mendasar tentang situasi yang potensial (jenis-jenis bencana atau krisis lain yang dapat terjadi, yang ditangani dan tindakan yang perlu dilakukan, besarnya biaya yang diperlukan, dsb. Keberagaman definisi menegaskan kesamaan pemahaman bahwa perencanaan kontinjensi harus mencakup proses pengaturan awal sehingga bisa membuat perencanaan atau menyusun strategi dan prosedur dalam menanggapi potensi krisis atau kedaruratan yang akan terjadi. Ini termasuk mengembangkan skenario (untuk mengantisipasi krisis), menentukan tanggung jawab semua pelaku yang akan terlibat mengidentifikasikan peran dan sumber daya, proses pendataan dan penyebaran informasi, dan pengaturan setiap pelaku sehingga siap pada saat dibutuhkan, dan menentukan kebutuhan agar tujuan tercapai. Perencanaan kontinjensi merupakan bagian penting dari keseluruhan program kesiapsiagaan dan perlu dikembangkan untuk setiap jenis bahaya, kemudian dimutakhirkan dan dilatihkan secara regular. ${ }^{22}$

Untuk memperkuat kesiapsiagaan terhadap bencana demi respon yang efektif di semua tingkat, maka Daerah Istimewa Yogyakarta telah membentuk

${ }^{20}$ Henny Dwi Vidiarina, Perencanaan Kontinjensi Tinjauan tentang beberapa Pedoman Perencanaan dan Rencana Kontinjensi, Kerjasama Indonesia-Jerman untuk Sistem Peringatan Dini Tsunami (GITEWS) Peningkatan Kapasitas Masyarakat Lokal, 2010, hlm. 8.

${ }^{21}$ Rencana Penanggulangan Bencana DIY 2013-2017, Badan Penanggulangan Bencana, 2013, hlm. 9

${ }^{22}$ Henny Dwi Vidiarina, Ibid., hlm. 9 
Badan Penanggulangan Bencana Daerah (BPBD) yang namun demikian BPBD yang ada perlu didukung dengan rencana kontinjensi untuk bencana yang mungkin terjadi pada jangka waktu dekat dalam skala besar. Rencana kontinjensi ini disusun untuk mempersiapkan cadangan finansial dan mekanisme lain yang dibutuhkan untuk proses penanganan darurat bencana dan pemulihannya.

Rencana kontinjensi ini perlu disusun sebagai pendukung penerapan prosedur operasi standar penanganan darurat untuk bencana-bencana prioritas di Daerah Istimewa Yogyakarta. Prosedur operasi standar penanganan darurat sebagai salah satu prioritas harus disusun dengan mengintegrasikan prosedur internal yang ada di setiap institusi terkait Penanggulangan Bencana di Daerah Istimewa Yogyakarta. ${ }^{23}$ Kebijakan Pemerintah Daerah Istimewa Yogyakarta dalam penanggulangan bencana, dilakukan melalui: ${ }^{24}$. Pembentukan lembaga penanggulangan bencana daerah; 2 . Integrasi Penanggulangan Bencana ke dalam arus utama pembangunan dan pemerintah; 3. Mengembangkan Sistem Pengurangan Risiko Bencana; 4. Meningkatkan Kapasitas semua sektor /komponen untuk proaktif terhadap penganggulangan bencana; 5. Menumbuhkembangkan budaya sadar bencana; 6 . Meningkatkan kualitas sumberdaya manusia lembaga penanggulangan bencana; 7 . Optimalisasi Pemulihan Bencana sehingga meningkatkan ketangguhan DIY.

Persiapan penanggulangan bencana secara preventif, maka diperlukan kesiapan melalui paradigm kontinjensi. Kontinjensi adalah suatu keadaan atau situasi yang diperkirakan akan segera terjadi, tetapi mungkin juga tidak akan terjadi. ${ }^{25}$ Tindakan perencanaan kontinjensi diwujudkan dalam rencana kontinjensi (Renkon). Renkon adalah suatu proses identifikasi dan penyusunan rencana yang didasarkan pada keadaan kontinjensi atau yang belum tentu tersebut. ${ }^{26}$ Suatu rencana kontinjensi mungkin tidak selalu pernah diaktifkan, jika keadaan yang diperkirakan tidak terjadi. UNHCR mendefinisikan rencana kontinjensi sebagai suatu proses perencanaan kedepan, dalam keadaan yang tidak menentu, dimana

\footnotetext{
${ }^{23}$ Ibid., hlm. 60

${ }^{24}$ Rencana Penanggulangan Bencana DIY 2013-2017, Badan Penanggulangan Bencana, 2013, hlm. 60

25 Slide 16 , Paparan FGD tanggal 4 Oktober 2016

${ }^{26}$ Ibid., slide 17
} 
skenario dan tujuan disepakati, tindakan teknis dan manajerial ditetapkan, dan sistem tanggapan dan pengerahan potensi disetujui bersama untuk mencegah, atau menanggulangi secara lebih baik dalam situasi darurat atau kritis. ${ }^{27}$ Penekanan renkon pada kesiapsiagaannya. Kesiapsiagaan bencana adalah: Suatu proses yang mengarah pada kesiapan dan kemampuan untuk memperkirakan kejadian bencana sehingga dapat: a. mencegah bencana; b. mengurangi dampak mereka; c. menanggapi secara efektif; d. memulihkan diri dari dampaknya.

RENKON harus dibuat secara bersama-sama oleh semua pihak (stakeholders) dan multi-sektor yang terlibat dan berperan dalam penanganan bencana, termasuk dari pemerintah (sektor-sektor terkait), perusahaan negara, swasta, organisasi nonpemerintah, lembaga internasional dan masyarakat. Suatu proses identifikasi dan penyusunan rencana yang didasarkan pada keadaan kontinjensi atau yang belum tentu tersebut. Suatu rencana kontinjensi mungkin tidak selalu pernah diaktifkan, jika keadaan yang diperkirakan tidak terjadi.

Terkait pula peraturan yang telah dimiliki BPBD Propinsi DIY, maupun BPBD Kota dan Kabupaten se DIY terjadi perkembangan yang pesat akhir-akhir ini. Pemerintah Prpoinsi DIY telah membuat Peraturan Daerah Provinsi Daerah Istimewa Yogyakarta Nomor 8 Tahun 2010 tentang Penanggulangan Bencana telah memberikan amanat untuk disusunnya pedoman penetapan status potensi bencana sebagaimana diatur dalam Pasal 31, Pasal 32, dan Pasal 3328. Pada akhir 2013, diselesaikan Peraturan Gubernur Nomor 11 Tahun 2013 tentang Pedoman Penetapan Status Bencana.

\section{Tahapan Penyusunan Rencana Kontinjensi}

Perencanaan kontinjensi merupakan bagian kehidupan sehari-hari. Diperlukannya perencanaan kontinjensi tergantung dari upaya mempertemukan antara besarnya

${ }^{27}$ Ibid., slide 18

${ }^{28}$ Pasal 31 ayat (1) Penentuan status potensi bencana di Daerah sebagaimana dimaksud dalam Pasal 27 huruf b dilakukan oleh Gubernur. (2) Dalam menentukan status potensi bencana sebagaimana dimaksud pada ayat (1), BPBD memberikan laporan kondisi bencana kepada Gubernur untuk kemudian ditetapkan.

Pasal 32 (1). Penetapan status potensi bencana didasarkan atas penilaian suatu keadaan bencana pada suatu wilayah sebagai dasar untuk menentukan kebijakan dan strategi penanggulangan bencana, serta penanggungjawab pada tingkat Daerah berdasarkan Pedoman Penetapan Status Potensi Bencana.

(2). Status potensi bencana sebagaimana dimaksud pada ayat (1) didasarkan pada pemantauan yang akurat oleh pihak yang berwenang.

(3). Status potensi bencana dibedakan menjadi: awas, siaga dan waspada Pasal 33 Ketentuan lebih lanjut mengenai pedoman penetapan status potensi bencana sebagaimana dimaksud dalam Pasal 32 ayat (1) diatur dengan Peraturan Gubernur. 
kejadian dengan tingkat dampak yang diakibatkan. Kegiatan penyusunan rencana kontijensi ini dilakukan dengan tahapan sebagai berikut: 1. Penyamaan persepsi terhadap semua pelaku penanggulangan bencana Merapi tentang pentingnya kontingensi plan; 2. Pengumpulan data dan updating; 3. Pengumpulan data dilakukan pada semua sektor penanganan; 4. Bencana dan lintas administratif; 5 . Verifikasi data; 6 . Analisa data sumber daya yang ada dibandingkan proyeksi kebutuhan penanganan bencana saat tanggap darurat; 7. Penyusunan rancangan awal kontinjensi plan; 8. Penyusunan naskah akademis, pembahasan dan perumusan dokumen kontingensi plan yang disepakati; 9. Publik hearing/konsultasi publik hasil rumusan kontingensi plan; 10. Penyebaran/diseminasi dokumen kontinjensi plan kepada semua pelaku penanggulangan bencana (multi stake holder).

Sifat rencana kontinjensi adalah single hazard, ${ }^{29}$ hanya digunakan untuk 1 jenis ancaman. Namun demikian, dalam hal bencana benar-benar terjadi, dimungkinkan terdapat dampak ikutan (collateral impact) atau bencana kedua (secondary disaster) yang merupakan bencana baru/bencana ikutan. Contoh, penyusunan rencana kontinjensi untuk menghadapi ancaman gempa bumi yang diikuti tsunami.

Perencanaan kontinjensi mencakup kegiatan-kegiatan yang dirancang untuk menghadapi kemungkinan terjadinya bencana/kedaruratan, antara lain: pengumpulan data/informasi (termasuk sumberdaya) dari berbagai unsur (pemerintah dan non-pemerintah) pembagian peran dan tanggungjawab antar sektor proyeksi kebutuhan lintas sektor identifikasi, inventarisasi dan penyiapan sumberdaya dari setiap sektor pemecahan masalah berdasarkan kesepakatankesepakatan. Komitmen/kesepakatan untuk melakukan peninjauan kembali/kaji ulang rencana kontinjensi, jika tidak terjadi bencana, termasuk dilaksanakan gladi. Penilaian Kebutuhan (need assessment) Agar bantuan yang diberikan pada korban sesuai dengan yang dibutuhkan, perlu dilakukan penilaian dengan mempertimbangkan kelompok umur, jenis kelamin, dan kelompok rentan lainnya.

${ }^{29}$ Hasil wawancara dengan Ir. Heri Siswanto, Kabid Penanggulangan dan kesiap siagaan Bencana BPBD DIY, tanggal. 22 Agustus 2016 
Susunan daftar penerima bantuan dapat dijadikan data awal dalam mempertimbangkan kebutuhan penerima bantuan. Mekanisme yang dilakukan pada kegiatan penilaian kebutuhan adalah sebagai berikut: 1) Langkah-langkah Mengidentifikasi kebutuhan penerima bantuan (korban bencana): a) Mengidentifikasi kebutuhan penerima bantuan; b) Menentukan prioritas bantuan yang diperlukan; c) Menyusun daftar kebutuhan berdasarkan prioritas yang diperlukan. 2) Mengidentifikasi sumber; a) Mengidentifikasi barang-barang/aset yang masih dimiliki korban/penerima bantuan; b) Mengidentifikasi pihak-pihak yang mungkin dilibatkan dalam penyediaan kebutuhan yang diperlukan penerima bantuan; c) Mengidentifikasi sumber-sumber lain di sekitar tempat penampungan. 3) Menentukan jenis bantuan yang diperlukan penerima bantuan (korban bencana): a) Berdasarkan identifikasi kebutuhan dan sumber, selanjutnya dapat ditentukan jenis bantuan apa saja yang diperlukan penerima bantuan; b) Selain daftar jenis bantuan dan pihak yang dapat dilibatkan, perlu disusun daftar kebutuhan yang diperlukan setiap hari, seminggu sekali, atau sebulan sekali pada masa tanggap darurat.

Beberapa Rencana Kontinjensi yang sudah dibuat oleh Pemerintah dilingkungan DIY tetapi belum dilaksanakan antara lain:

\section{Kontinjensi bencana Erupsi Gunung Merapi}

Aktivasi rencana kontijensi dilaksanakan setelah terdapat tanda- tanda peringatan dini akan datangnya ancaman G. Merapi dari hasil kajian lembaga teknis "BPPTK" Yogyakarta pada saat status aktivitas Merapi "SIAGA". Dalam rencana kontijensi bencana Erupsi Gunung Merapi Pemerintah Kabupaten Sleman mengambil beberapa kebijakan yang merupakan penetapan landasan kegiatan untuk mencapai penanggulanagan bencana yang efektif dan strategi untuk dikoordinasikan ke segenap jajaran yang terkait.

Perencanaan sektoral ditujukan untuk mencapai penanganan bencana alam yang dapat melindungi segenap masyarakat. Perencanaan sektoral dilakukan sebagai fungsi manajemen penanganan bencana yang telah melakukan evaluasi terhadap tingkatan ancaman yang terjadi, prinsip evakuasi pengungsian untuk perlindungan masyarakat sementara, dan akan menata kembali kehidupan 
setelah pasca bencana. Perencanaan sektoral terdiri atas: 1. Sektor manajemen dan koordinasi; 2. Sektor kesehatan; 3. Sektor sarana prasarana; 4. Sektor logistik.

\section{Rencana Kotinjensi Gempa Bumi}

Kabupaten Kulon Progo telah memiliki Badan Penanggulangan Bencana Daerah (BPBD) yang dibentuk pada Januari 2011 diketuai oleh Sekretaris Daerah Kabupaten Kulon Progo, dan dalam operasional sehari-hari dilaksanakan oleh Kepala Pelaksana BPBD Kabupaten Kulon Progo. Pada 2011 telah diprogramkan sosialisasi tentang kesiapan untuk menghadapi bencana di desa-desa untuk lebih meningkatkan kesiapan. Pada saat ini masyarakat secara mandiri telah membuat tempat-tempat pengungsian maupun cadangan logistik yang diperlukan pada tempat-tempat yang lebih tinggi. Perencanaan sektoral terdiri atas: 1. Sektor manajemen dan koordinasi; 2. Sektor kesehatan; 3. Sektor sarana prasarana; 4. Sektor logistic, 5. Sektor SAR, Sektor Transportasi.

\section{Rencana kontinjensi Gempa Bumi}

Kejadian ditetapkan berdasarkan kesepakatan, melalui penilaian resiko dan penetapan secara top-down. Diprediksi akan terjadi gempa bumi dengan magnitudo 8 Skala Richter, kedalaman lebih kurang $30 \mathrm{~km}$ atau gempa dangkal, pusat gempa bumi (epicentre) berjarak sekitar $150 \mathrm{~km}$ dari garis pantai yang diikuti tsunami dengan ketinggian gelombang mencapai 5 meter yang melewati 4 kecamatan yaitu Kecamatan Temon, Kecamatan Wates, Kecamatan Panjatan, dan Kecamatan Galur. Gelombang tsunami akan menyapu sebagian besar wilayah dataran pantai yang diantaranya ditempati oleh 4 kecamatan tersebut.

Sebagian dampak guncangan gempa bumi tidak menimbulkan kerusakan serius, namun selang sekitar 30 menit kemudian datanglah gelombang laut raksasa yang akan menyapu kawasan pantai dengan membawa material landaan berupa vegetasi pantai, perahu-perahu nelayan, puing-puing rumah, kios-kios wisata, nelayan dan lain-lain. Hal inilah yang berpotensi akan menyebabkan bencana di sepanjang kawasan pantai Kulon Progo dan sekitar muara sungai Bogowonto dan 
Progo, karena sungai tersebut merupakan jalan masuk arus tsunami dan mengancam pemukiman penduduk.

\section{Rencana Kontinjensi Tsunami Kab. Kulonprogo}

Kabupaten Kulon Progo merupakan salah satu dari lima daerah Kabupaten/Kota di Provinsi Daerah Istimewa Yogyakarta, kewilayahan ditandai di sebelah barat berbatasan dengan Kabupaten Purworejo Provinsi Jawa Tengah, sebelah timur berbatasan dengan Kabupaten Sleman dan Bantul sedangkan di sebelah utara berbatasan dengan Kabupaten Magelang Provinsi Jawa Tengah serta bagian selatan berbatasan langsung dengan Samudera Indonesia atau Samudera Hindia. Tingkat ancaman dalam Rencana Kontinjensi ini dari hasil diskusi dan kesepakatan dengan semua peserta adalah ancaman berat, sehingga skenario yang digunakan adalah skenario dengan risiko berat, sebagai berikut: 1) Gelombang tsunami diperkirakan akan mencapai sepanjang garis pantai Kabupaten Kulon Progo dalam waktu sekitar 30 menit setelah gempa terjadi; 2) Jarak landaan (inundation) di beberapa tempat akan masuk ke daratan sekitar $2 \mathrm{~km}$, tergantung pada bentuk topografi daratan. Sedangkan pada topografi berbukit, akan kurang dari jarak tersebut. Run up di daratan akan berkisar antara 0-7 km. Sedangkan ketinggian gelombang di garis pantai diperkirakan mencapai sekitar 5 meter; 3) Kerusakan infrastruktur/bangunan juga dapat terjadi akibat guncangan gempa dengan magnitudo pada 8,5 Skala Richter.

Hal-hal tersebut berpotensi menimbulkan bencana bagi masyarakat yang bermukim di daerah tepi pantai serta dapat merusak sarana dan prasarana termasuk fasilitas umum. Perlu lebih diwaspadai, daerah di 4 kecamatan yaitu: Kecamatan Temon, Kecamatan Wates, Kecamatan Panjatan, dan Kecamatan Galur yang tersebar di sepanjang garis pantai Kabupaten Kulon Progo, karena gelombang tsunami akan masuk melalui aliran sungai tersebut dengan cepat dan tinggi karena daerah dekat aliran sungai-sungai tersebut akan terjangkau genangan air laut.

\section{Penutup}

Kewenangan yang ada pada penyelenggara administrasi negara yang dikenal dalam hukum administrasi negara yaitu asas diskresi. Penggunaan diskresi pada penanggulangan bencana di atas dapat disimpulkan bahwa: pertama, diskresi 
ditujukan untuk menjalankan tugas-tugas servis public yang merupakan sikap tindak yang aktif dari administrasi negara dalam hal ini Gubernur DIY, Bupati Bantul, Walikota Yogyakarta dan Bupati Sleman yang dimungkinkan oleh hukum dengan inisiatif untuk menyelesaikan persoalan persoalan penting yang timbul secara tiba tiba dapat dipertanggung jawab harus diberi ruang. Mengacu pada konsepsi hukum responsif, maka diskresi justru luas tetapi tetap sesuai dengan tujuan, sedang tujuan dari peraturan kebijaksanaan akibat digunakannya asas diskresi adalah menitik beratkan pada kemanfaatan (doelmatigeid). Kedua, pada umumnya Penanggulangan bencana yang ada masih bersifat serta merta dan ad hoc sehingga masih menitik beratkan pada penanganan pasca bencana, karena belum ada perencanaan dan prediksi kejadian bencana. Dengan paradigma kontinjensi kejadian bencana yang belum terjadi tetapi mungkin terjadi dapat dirancang penanggulangannya melalui rencana kontinjensi. Beberapa rencana kontinjensi sudah dibuat oleh BPBD di wilayah DIY. Namun belum ada kesamaan prosedur pengawasan pasca renkon diantivasi maupun jika renkon tidak jadi diaktivasi karena bencana yang di prediksi tidak terjadi.

Saran yang diajukan dari hasil peneliti ini, pertama, penanggulangan bencana berparadigma kontinjensi dimasukkan dalam Pearturan Gubernuh penyelenggaraan penanggulangan bencana di Daerah Istimewa Yogyakarta disertai pengaeasan dan evaluasi dampak renkon yang diaktivasi maupun tidak. Kedua, dibuat prosedur yang harus dilakukan disesuaikan dengan perkembangan kebutuhan dan difokuskan untuk membangun serta memperkuat jejaring partisipasi semua pihak;

\section{Daftar Pustaka}

\section{Buku}

Sulistiyono, Bambang, Prediksi Genangan Kali Code di Kota Yogyakarta Pasca Erupsi Merapi 2010, DPPM UII, Yogyakarta, 2010.

Blaang, C. Djemabut, Permukiman dan Perumahan Sebagai Kebutuhan Pokok, Yayasan Obor Indonesia, Jakarta, 1998.

Dwiyanto, Agus, dkk, Reformasi Tata Pemerintahan dan Otonomi Daerah, Pusat Studi Kependudukan dan Kebijakan UGM, Yogyakarta, 2003. 
Galligan, D. J , Discretionary Power, Oxford Press University, New York, 1990.

Hutabarat, Martin H. dkk. (penyunting), Hukum dan Politik Indonesia Tinjauan Analitis Dekrit Presiden dan Otonomi Daerah, Pustaka Sinar Harapan, Jakarta, 1996.

Kusumaatmadja, Mochtar, Fungsi dan Perkembangan Hukum Dalam Pembangunan Nasional, Alumni, Bandung, 1994.

Liesnoor Dewi, Erosi dan Mitigasi Bencana, (Buku Ajar) Jurusan Geografi, UNNES, CV. Sanggar Krida Aditama, Semarang, 2010.

Muchsan, Sistem Pengawasan Terhadap Perbuatan Aparat Pemerintah dan Peradilan Tata Usaha Negara di Indonesia, Liberty, Yogyakarta, 1992.

Hajon, Philipus M., Pengantar Hukum Administrasi Indonesia, Gajah Mada University Press, Yogyakarta, 1993.

Nonet, Philippe, dan Philip Zelnick, Hukum Responsif, (terj: Raisul Muttaqien), Nusamedia, Bandung, 2007.

Admosudirdjo, Prajudi, Hukum Administrasi Negara, Ghalia Indonesia, Jakarta, 1981.

HR, Ridwan, Hukum Administrasi Negara, UII Press, Yogyakarta, 2002.

Marbun, SF., et (Penyunting), Dimensi-Dimensi Pemikiran Hukum Administrasi Negara, UII Press, Yogyakarta, 20

Wignyosoebroto, Soetandyo, Hukum, Paradigma, Metode dan Dinamika Masalahnya, ELSAM dan HUma, Jakarta, 2002.

Tatang M. Amirin, Menyusun Rencana Peneritian, Rajawali Pers, Jakarta, 1990.

Utrecht, A., Pengantar Hukum Administrasi, Pustaka Tinta Mas, Surabaya, 1988.

Warsito Utomo, Administrasi Publik Bam Indonesia, Pustaka Pelajar, Yogyakarta, 2006.

\section{Jurnal}

Sulastriyono, dkk., Pola Penguasaan dan Upaya Penataan Tanah Wedi Kengser di Tepi Sungai Code dalam Rangka Otonomi daerah di Yogyakarta, Yogyakarta, Mimbar Hukum Fakultas Hukum UGM Yogyakarta, 2002.

Yang Yang, "Fundamental Research on the Administrative Discretion Standard" Beijing Law Review, 2012, 3, 128-132 2014

\section{Internet}

Jawahir Thontowi, Legal System to related Sediment and Natural Disater in Indonesia, Conducted by Joining to Collaboration Between JICA Japan and IMPRESS Daerah Istimewa Yogyakarta, Indonesia, 2004.

http://dx.doi.org/10.4236/blr.2012.33017 Published Online September 2012, (http:/ / www.SciRP.org/journal/blr) 
http://www.tribunnews.com/2011/04/30/aliran-lahar-dingin-merapi-bisa-berlangsung-4tahun.

\section{Hasil Penelitian Terdahulu}

Eko Suharto, Bambang, Responsivitas dan Akuntabilitas Pemerintah Lokal dalam Menuju Good Governance (Disertasi) Fakultas Ilmu Administrasi Universitas Brawijaya. Malang, 2010 